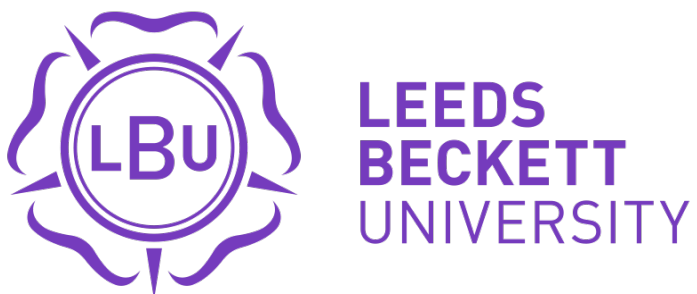

Citation:

Shore, $H$ (2011) Criminality and Englishness in the aftermath: The racecourse wars of the 1920s. Twentieth Century British History, 22 (4). 474 - $497 . \quad$ ISSN 0955-2359 DOI: https://doi.org/10.1093/tcbh/hwr011

Link to Leeds Beckett Repository record:

https://eprints.leedsbeckett.ac.uk/id/eprint/120/

Document Version:

Article (Accepted Version)

The aim of the Leeds Beckett Repository is to provide open access to our research, as required by funder policies and permitted by publishers and copyright law.

The Leeds Beckett repository holds a wide range of publications, each of which has been checked for copyright and the relevant embargo period has been applied by the Research Services team.

We operate on a standard take-down policy. If you are the author or publisher of an output and you would like it removed from the repository, please contact us and we will investigate on a case-by-case basis.

Each thesis in the repository has been cleared where necessary by the author for third party copyright. If you would like a thesis to be removed from the repository or believe there is an issue with copyright, please contact us on openaccess@leedsbeckett.ac.uk and we will investigate on a case-by-case basis. 


\title{
Criminality and Englishness in the Aftermath: The Racecourse wars of the 1920s
}

\begin{abstract}
This article explores the extent to which post-war concerns about Englishness and fears about 'the enemy within' shaped understandings of the 'racecourse wars' of the 1920s. These conflicts involved mainly metropolitan criminals in various affrays and fights on the streets of London, and on the racecourses of South-east England. The press coverage of the events has been described as akin to a 'moral panic' and certainly they provided serious headline fodder during the peaks of 1922 and 1925. Moreover, the key personnel of these 'wars', arguably dramatically overwritten by the press, have become signposts in the chronology of twentieth-century British organized crime. This article will draw upon newspaper reports, police autobiography, trial reports, metropolitan police records and correspondence with the army, to explore concerns about the nature and prevalence of gang crime and forms of inter-personal violence.

Keywords: Crime, Englishness, Gangs, Gambling, Alienism
\end{abstract}

This article considers the shaping of attitudes to crime and criminality in Britain in the aftermath of the Great War. Between 1920 and 1925 police and press were concerned with a series of outbreaks of violence that became known collectively as the 'Racecourse Wars'. These conflicts involved mainly metropolitan criminals in affrays and fights on the streets of London and on the racecourses of South-east England. The core objective of the racecourse gangs was in securing the control of the protection business, which basically took the form of offering 'protection' to bookmakers and intimidating their rivals, and then taking a share of the earnings from the pitch. Bookmakers on the most 
profitable pitches who did not comply were threatened with violence until they moved off or submitted to the gangs' demands. Whilst this form of intimidation was not a new feature of the bookmaking industry, in the post-war period it seems to have become increasingly organised. The business in the Midlands and the south-east was dominated by two main groups (the Birmingham boys, led by William Kimber, and the Sabini gang, led by Charles 'Darby' Sabini) and the confrontations of the period seem initially to have derived from their battles over territory. However, by 1921 the conflicts over territory extended from the racecourses and into the public spaces and streets of the metropolis. ${ }^{1}$

The press dramatically sensationalised both the protagonists and events of these 'wars'. Subsequently (and perhaps consequently), the 'racecourse wars' have tended to be considered as part of a genealogy of British organised crime, with the Sabinis established as the first 'family firm' in this trajectory. ${ }^{2}$ In contrast, here I will argue that these events need to be more closely contextualised in the post-war period. Whilst there had been concerns about degeneration and delinquency prior to the First World War, the relationship between gender and criminality would increasingly influence the narratives of crime that were constructed in the aftermath. ${ }^{3}$ Contemporary views about masculinity and criminality also shaped the construction of Englishness in a period during which the

\footnotetext{
${ }^{1}$ James Morton, East End Gangland (London, 2000), pp. 119-140.

${ }^{2}$ According to the popular 'gangland' narrative of the Sabini gang, their activities extended beyond racecourse protection and illegal gambling, and into theft, extortion, and the nightclub business. However there is clear no evidence of their involvement in the wider organisation of crime in the metropolis. Philip Jenkins and Gary W. Potter, 'Before the Krays: Organized Crime in London, 1920-1960', Criminal Justice History: An International Annual, 11 (1988), pp.209-230.

${ }^{3}$ For example see Shani D'Cruze, 'Intimacy, Professionalism and Domestic Homicide in Interwar Britain: the case of Buck Ruxton', Women's History Review, 16/5 (2007), pp. 701-722; John Carter Wood, "'Those Who Have Had Trouble Can Sympathise with You": Press Writing, Reader Responses and a Murder Trial in Interwar Britain', Journal of Social History, 43/2 (2009), pp. 439-462. For pre-war see Daniel Pick, Faces of Degeneration: A European Disorder, c. 1848-1918 (Cambridge University Press, 1989).
} 
boundaries of national character were being re-drawn. ${ }^{4}$ As Matt Houlbrook has argued, 'it is clear that many Briton's experienced this as a moment of profound dislocation that threatened to destabilize the boundaries between classes, sexes, and races on which the nations stability depended' ${ }^{5}$ Arguably, the race-gang member can be seen as a product of this de-stabilisation - unmanned by war and violence; un-English, and even alien, in the case of Italian and Jewish gang members; a 'menace to the community'. ${ }^{6}$ As Jon Lawrence has argued, it was important for Briton's in the post-war period to re-work myths of Britain as a 'peaceable nation'. ${ }^{7}$ On a similar note, Clive Emsley has argued that there was a decreasing tolerance for violence after the war. Despite a variety of commentators who expressed concern about post-war violence, and marginal rises in the murder rate, he argues that there was little stomach for sensationalism in 1919. However, this reticence does not seem to have extended to the press coverage of the racecourse gangs by the early 1920s. Arguably, this was a brand of thuggery that sat particularly ill in a period where the appetite for physical conflict had been so dramatically exhausted.

The press coverage of these events has been described as akin to a 'moral panic' and certainly they provided serious headline fodder during the peaks of 1922 and $1925 .^{8}$ How far 'moral panic' is a useful means of considering these events is debateable. The

\footnotetext{
${ }^{4}$ For example, Susan Kingsley Kent, Making Peace: The Reconstruction of Gender in Interwar Britain (Princeton University Press, 1993); Lucy Noakes, 'Demobilising the Military Woman: Constructions of Class and Gender in Britain After the First World War', Gender and History, 19/1 (2007), pp. 143 - 162; Michael Roper, 'Between Manliness and Masculinity: The 'War Generation' and the Psychology of Fear in Britain, 1914 - 1950, Journal of British Studies, 44/2 (2005), pp. 343 - 362.

${ }^{5}$ Matt Houlbrook, 'The Man with the Powder Puff' in Interwar London', The Historical Journal, 50/1 (2007), pp. 145-171, at p. 160. See also Susan Kingsley Kent, Aftershocks: Politics and Trauma in Britain, 1918 - 1931 (Palgrave Macmillan, 2009).

6 'Race Gang Menace', Daily Mail, 24 August 1925.

${ }^{7}$ Clive Emsley, 'Violent Crime in England in 1919: Post-War Anxieties and Press Narratives', Continuity and Change, 23/1 (2008), pp. 173 - 195; Jon Lawrence, 'Forging a Peaceable Kingdom: War, Violence, and Fear of Brutalisation in Post-First World War Britain', The Journal of Modern History 75, September (2003), pp.557-589.

${ }^{8}$ Mike Huggins, Horseracing and the British 1919-39 (Manchester, 2003), p.11.
} 
description of public and official anxiety as a 'moral panic' suggests that the response to a set of events is disproportionate. As P. A. J. Waddington suggests, studies of 'moral panics' have tended to focus upon the scale of the response rather than the scale of the problem. ${ }^{9}$ The events upon which this article will focus were relatively small-scale and their impact local. Nevertheless, whilst these events may not have amounted to a classic 'moral panic' - violent crime rates did not soar, legislation was not passed - the construction of the gang-members as 'folk-devils' should be considered. ${ }^{10}$ Thus Goode and Ben-Yehuda define the 'folk-devil' 'as a "suitable enemy", the agent responsible for the threatening or damaging behaviour or condition'. ${ }^{11}$ In the 1920 s the form of such representation would vary across the range of institutions and agencies that collectively contributed to the construction of the racecourse gangs. The most familiar version would cast the gang members as aliens and outsiders, drawing on fears of 'alien invasion' that had been circulating since the previous century. ${ }^{12}$ Significantly, it would be the association of the racing-men with Jewish bookmakers that provoked the most unambiguously 'alienist' language, reflecting David Cesarani's view of the essentially anti-semitic nature of post-war measures. ${ }^{13}$ In contrast, I will argue here that the language used to describe the 'racecourse wars' frequently drew on prevailing ideas of

\footnotetext{
${ }^{9}$ P. A. J. Waddington, 'Mugging as a Moral Panic: A Question of Proportion', The British Journal of Sociology, 37/2 (1986), pp. 245-259, pp. 245-46. For the classic concept of 'moral panic' see Stanley Cohen, Folk Devils and Moral Panics (London, 1972).

${ }^{10}$ Clive Emsley, Hard Men: Violence in England Since 1700 (London, 2005), pp. 19-22.

${ }^{11}$ Erich Goode and Nachman Ben-Yehuda, Moral Panics: The Social Construction of Deviance (Chichester, 2007), p. 27.

${ }^{12}$ William Henry Wilkins, The Alien Invasion (London, 1892). See also Clive Emsley, Crime and Society in Twentieth-Century England (Harlow, 2011), pp. 45-46.

${ }^{13}$ David Cesarani, 'An Alien Concept? The Continuity of Anti-alienism in British Society before 1940', in David Cesarani \& Tony Kushner (eds), The Internment of Aliens in Twentieth Century Britain (London, 1993), pp.25-52, p. 37; idem, 'Anti-Alienism in England after the First World War', Immigrants and Minorities, 6/1 (1987), pp. 5-29, p. 7.
} 
'Englishness' rather than anti-alienism. ${ }^{14}$ The male gang members would be explained in a variety of ways over the course of the first half of the 1920s, most of which pointed to a form of masculinity that was in some way 'other' to the understanding of 'Englishness' that was being worked out in the aftermath. Thus the presence of Italians amongst the racing-men would provide, for some commentators, a means of explaining such 'unEnglish' behaviour as razor slashing. The association between violence and 'unEnglishness' was not particularly new in the post-war. ${ }^{15}$ Indeed, Martin Wiener has noted that in the nineteenth century perceptions of criminal behaviour intertwined with the construction of a 'modern English national identity'. In relation to knife-fighting in particular, Wiener notes that the judiciary aimed to make their use a 'mark of exclusion from the national community' - moreover Italians were frequently identified with crimes involving knives, a form of violence which court-rooms presented as an innate feature of the Italian character and temperament. ${ }^{16}$ This association between the Italian race-gang members and such forms of apparently 'un-English' violence was still frequently deployed by the press in the post-war period. Moreover, anonymous letters to the police and Home Office received in 1922 and 1923 would also draw upon distinctions between 'Englishmen' and 'Foreigners' in their accusatory narratives of the race-gang violence. ${ }^{17}$ However, not surprisingly, the tone of these narratives was significantly heightened in the aftermath. Moreover, 'Englishness' was not the only trope which police and press would employ to explain and question the race-gang violence. ${ }^{18}$ Thus police and press drew on

\footnotetext{
${ }^{14}$ Krishan Kumar, 'Englishness' and English National Identity’, in David Morley and Kevin Roberts (eds), British Cultural Studies: Geography, Nationality and Identity (Oxford, 2001), pp. 41-55, p. 48.

${ }^{15}$ Emsley, Hard Men, pp. 81-83.

${ }^{16}$ Martin Wiener, 'Homicide and 'Englishness': Criminal Justice and National Identity in Victorian England’, National Identities, 6/3 (2004), pp. 203-13, pp. 203, 205-7.

17 TNA: HO 144/10430 and MEPO 3/1581.

${ }^{18}$ Colin Holmes (ed.), Immigrants and Minorities in British Society (London, 1978).
} 
the language of conflict, which further emphasised the essential 'un-Englishness' of the violence. Thus during the 1920s, simple if effective descriptions of 'ruffianism' and 'rowdyism', were often shadowed by a more sinister language which drew upon the worrying idea of the 'enemy within'. Military metaphors were frequently employed and references to terrorism, insurrection, vendettas, and espionage can be found throughout the period.

The article will draw upon the extensive press coverage and the large collection of Home Office and Metropolitan Police files that survive at the National Archive, to explore attitudes to the racecourse gangs. Using the lens of three key groups to consider post-war attitudes to the race-gang violence: police, anonymous writers, and press, this article will explore the relationship between the impact of war and violent crime in the period. A key theme will be the extent to which the racecourse conflicts of the 1920s came to provide a 'folk devil' in a period during which there were no easy formulations for dealing with soldier 'heroes'. Concerns were increasingly expressed about the soldier who was at risk of committing crime, thus becoming a criminal as a result of the trauma of war. ${ }^{19}$ As T. W. Standwell asked in 1920, 'Are You a Potential Post-War Criminal?'20 Yet whilst masculinity was frequently rewritten through the experience of the British soldier, the 'Tommy', the criminal arguably existed antagonistically to the returning exservicemen. Not surprisingly, considerable numbers of these 'folk devils' had themselves seen military service. Thus police enquiries into infantry records were a common practice in the investigations into the incidents of 1921 to 22 . But the police also saw the

\footnotetext{
${ }^{19}$ On the impact of war on returning soldiers see, 'Introduction: Embodiment', in Joanna Bourke, Dismembering the Male: Men's Bodies, Britain and the Great War (London, 1996), pp. 11-30, esp. pp. 1118; Graham Dawson, Soldier Heroes: British Adventure, Empire and the Imaginings of Masculinity (London, 1994).
} 
racecourse 'wars' as essentially a product of press exaggeration. Adrian Bingham has stressed the importance of examining popular newspapers; it was only in this period that the habit of reading a daily paper became widely entrenched. ${ }^{21}$ Thus, Bingham argues, they represent a considerable contribution to the "public and political discourse of the period'. ${ }^{22}$ Part one will sketch the major events in the racecourse-wars and outline the key individuals and networks involved. It will also provide some contextual background to the expansion of racecourse betting and gambling practices. Part two will more closely consider the police and press formulations of the racecourse wars, arguing that rather than drawing on simple knee-jerk representations of the gangs as alien and foreign, the police acted in response to a press coverage that stressed the impact of war, the threat to public safety, and the 'terrorism' perpetuated by the racing ruffians.

\section{Part One}

\section{Key Events in the Racecourse Wars}

The chronology of the 'racecourse wars' is chiefly shaped by the press reporting of a number of events that were either clearly or loosely connected. However, two considerations need to be taken into account. Firstly, the press coverage and, to a large extent, the police investigations into the race-gangs were limited to a specific time frame. This was the period between spring 1921 and roughly the mid-1920s. The most intense reporting came between March 1921 and August 1922, and between February and August 1925. Nevertheless, the gangs did not arrive in the 1920 s fully formed and it is

\footnotetext{
${ }^{20}$ T. W. Standwell, 'Are You a Potential Post-War Criminal?', Health and Strength, 24 January 1920.

${ }^{21}$ Adrian Bingham, Gender, Modernity and the Popular Press in Inter-War Britain (Oxford, 2004), pp. 4, 8-10. Alongside The Times, I have drawn widely on the popular press. As Bingham states, the market was dominated by conservative-leaning papers such as the Daily Mail, Daily Express, and Daily Mirror (which did not move to the left until the mid-1930s). The Evening Standard tended to follow lead of the Mail and the Express. As a Sunday paper, The News of the World directed its main appeal to working-class audiences. Bingham, Gender, pp. 12-14.
} 
clear that a number of the men had pre-war records, and certainly in the case of the Sabinis, were long-standing members of their local communities. In March 1921, when 'Darby' (as Charles) Sabini was charged with grievous bodily harm, he was already aged around $32 .{ }^{23}$ Moreover, the violence and particularly racing related illegalities continued into the 1930s, with the involvement of members of the Sabini family (at least until the internment of Charles and Harry Sabini in 1940), as well as their close allies the White family. ${ }^{24}$ The second factor to consider is the way in which the press and police defined the racecourse wars. In metropolitan police files compiled during the 1920 s, there is a definitive list of 'events'; these are partly based on police knowledge and press reportage, and partly on anonymous letters sent to the police. ${ }^{25}$ From the point of view of the press, race-gang crimes were marked by large conflicts in metropolitan spaces, involving razors, knives and firearms. On the other hand, for the police race-gang crime was more strongly associated with the alliances of 'known' individuals, such as the Sabini brothers and their overlapping networks. The first widely reported incident took place in spring 1921, when Charles 'Darby' Sabini was charged with shooting with intent to do grievous bodily harm and possessing a revolver without a permit at Greenford Trotting track in Middlesex, on 23 March. ${ }^{26}$ At the same time that Sabini was being charged, the Daily Mirror reported on the shooting of William Kimber, the 'leader' of the Birmingham boys, and a key adversary of the Sabini family. ${ }^{27}$ The next 'event' occurred in June that year when a group of Jewish bookmakers from Leeds were attacked on the road from Epsom

\footnotetext{
${ }^{22}$ Ibid. p. 12.

${ }^{23}$ London Metropolitan Archive [hereafter LMA]: PS/B/E/1/2: Ealing Magistrate Court Register.

${ }^{24}$ TNA: HO 45/23691, 'Octavius Sabini: Internment'; HO 45/25720, 'Defence Regulation 18B Detainees: SABINI, Harry'.

${ }^{25}$ TNA: HO 144/10430, 'Racecourse ruffians: activities of the "Sabini" gang'

${ }^{26}$ LMA: PS/B/E/1/2, Ealing Magistrate Court Register.

${ }^{27}$ Daily Mirror, 29 March, 1921.
} 
to Ewell by a party of armed men. ${ }^{28}$ The police soon linked the affray to the Birmingham gang, who had apparently mistaken the Leeds bookmakers for the Sabini gang. A number of related incidents can be traced throughout the followings months. ${ }^{29}$ However, an escalation of the 'racecourse wars' would occur from the summer of 1922 with a series of incidents which essentially amounted to a turf war between the Birmingham gang (also known as the Elephant gang) and the Sabini gang, most of which took place on metropolitan streets rather than on the racecourses. In late July 1922 a shooting affray in the Gray's Inn Road was headline news. The Evening Standard reported, 'Shots In London Street' - Exciting Chase In Gray's Inn Road - Police Under Fire'. A number of men known to be associated with the Sabini gang were charged with feloniously shooting at a Flying Squad Detective named Rutherford, who was apparently 'keeping observation, ${ }^{30}$ The following month a further shooting took place in Mornington Crescent, when shots were fired at Elephant gang member, Frederick Gilbert. The two cases were dealt with together at the Central Criminal Court, and a number of gang members (from both sides) were sentenced to penal servitude. ${ }^{31}$ Finally, in November 1922, Harry Sabini was shot in the stomach by a member of a rival family (and former allies), the Cortesis, at the Fratellanza Club in Clerkenwell. ${ }^{32}$ Augustus and Enrico Cortesi were found guilty of shooting at Charles and Harry Sabini with the intent to

\footnotetext{
${ }^{28}$ The Times, 4 June 1921; see also The Times, 3 June 1921; Epsom Herald, 10, 17 June, 1 July 1921, Surrey Advertiser and County Times, 23 July 1921, Sunday Express, 24 July 1921; TNA: MEPO 3/346, 'Affray at Ewell known as "The Epsom Hold-Up" on 2 June 1921 following race meeting'.

${ }^{29}$ Morton, East End, pp.119 - 140 .

${ }^{30}$ The Evening Standard, 29 July, 1922; The News of the World, 6 August 1922; LMA: PS/CLE/A1/61, Clerkenwell Police Court Register, 1, 7, 10, 12 August 1922.

${ }^{31}$ The Times, 4 November 1922.

${ }^{32}$ LMA: PS/CLE/A1/62 - 63, Clerkenwell Police Court Registers, 21, 28 November, 5, 13 December, 1922,; also PS/CLE/B2/44, Charge Book; TNA: CRIM 1/209, 'Cortesi, Augustus Cortesi, George Cortesi, Paul Cortesi, Enrico Tomaso, Alexander Charge: Attempted murder'.
} 
murder at the Old Bailey in January 1923, and sentenced to three years penal servitude. ${ }^{33}$ A note added to the minutes commented, 'It is perhaps a pity that the Cortesi brothers are not being charged with the murder of the brothers Sabini'. ${ }^{34}$ With so many gang members in prison there was a period of relative quiet during the following couple of years. ${ }^{35}$ The Sabinis did not entirely disappear from the public eye. For example, a Sabini associate named Alfred Solomon was charged with the murder of a bookmaker's runner in November 1924. ${ }^{36}$ By 1925 events once again escalated. A series of incidents were reported in the press between February and August 1925. Most noteworthy on the evening of 20 August, there was a pitched battle apparently involving 50 men fighting with razors on the corner of Aldgate and Middlesex Street in the City of London. ${ }^{37}$ These events provoked a series of inflammatory headlines and editorials, which were further fuelled by the campaigning of Home Secretary William Joynson-Hicks who by August 1925 had declared 'War on the Race-gangs'. ${ }^{38}$

The 'Italian gang' or Sabini gang were key protagonists in these events. However, there were a number of overlapping circles. The core personnel involved were associated with one of three groups: The Sabinis, an Anglo - Italian family from Clerkenwell, headed by Charles or Darby Sabini; the Elephant Gang, a group of men from the Elephant and Castle, in South London, and from Birmingham, headed by William 'Billy' Kimber and their associate Fred Gilbert of the Camden Town Gang; finally various Jewish bookmakers led by Edward Emmanuel, and their associates, such as Alfred

\footnotetext{
${ }^{33}$ The Times, 19 January 1923.

34 TNA: HO 144/10430, 'Minutes, Oct 1922'.

${ }^{35}$ See 'Court of Criminal Appeal. Racecourse Feud: A Conviction Crossed' 20 December 1922. Also TNA: MEPO 3/1581, 'Report from Wm Boothby, 20 August 1922'.

${ }^{36}$ The Times, 2, 10 October, 18 November 1922; The Morning Advertiser, 19 November, 1924; TNA:

MEPO 3/374, 'Alfred SOLOMON charged with wilful murder of Barnet BLITZ...'

${ }^{37}$ TNA: HO 144/10430, 'Reports from Superintendent Thomas Faulkner, 23, 24 August 1925'.
} 
White. Descriptions of these groups as 'gangs' or 'organised' criminals are essentially problematic. Clive Emsley has suggested that 'it is unlikely that more than a few offenders were "professionals" for whom crime was the principal source of income'. ${ }^{39}$ Criminologists have pointed out the problems in defining organised crime, questioning the concepts of structure and hierarchy that have fundamentally informed both academic and governmental definitions. ${ }^{40}$ In the 1980s, Peter Reuter coined the term 'disorganised' crime, arguing that in reality criminal networks were more diverse and fragmented than the traditional picture had supposed. ${ }^{41}$ This is perhaps a more useful means of categorising the criminal activity in which the gangs were supposedly involved. This is suggested most significantly by the fundamentally loose nature of these alliances, with men switching allegiances, or groups joining forces when territorial concerns shifted. ${ }^{42}$ Other criminologists have emphasised the importance of kinship and ethnicity in being the main forces that shaped early criminal networks. ${ }^{43}$ Clearly in the case of the racecourse gangs ethnicity was a consideration. Whilst the Sabinis were British-born, and only half-Italian, they lived and worked in the heart of the Italian community of Clerkenwell. ${ }^{44}$ Moreover, cross-alliances with other ethnic groups came into play when territory needed to be defended. It is likely that the Sabinis closeness to the East End gang was related to the predominance of Jews in the bookmaking trade. However, these

\footnotetext{
${ }^{38}$ Daily Express, 24 August 1925.

${ }^{39}$ Clive Emsley, 'The History of Crime and Crime Control', in Mike Maguire, Rod Morgan and Robert Reiner (eds), The Oxford Handbook of Criminology (Oxford, $3^{\text {rd }}$ edn., 2002), pp. 203-30, at p. 210.

${ }^{40}$ Alan Wright, Organised Crime (Cullompton, 2006), pp. 2, passim.

${ }^{41}$ Peter Reuter, Disorganised Crime: Illegal Markets and the Mafia - The Economics of the Visible Hand (Cambridge, MA, 1983).

${ }^{42}$ See Andrew Davies, 'Street Gangs, Crime and Policing in Glasgow During the 1930s: The Case of the Beehive Boys', Journal of Social History, 32/2 (1998), pp.349-69.

${ }^{43}$ See Jenkins and Potter, 'Before the Krays', p. 222; Dick Hobbs, 'Organised Crime Families', Criminal Justice Matters, 50/1 (2002), pp. 26-27.
} 
alliances were far from clean-cut and the popular accounts of the gangs seem to suggest a certain amount of manoeuvring and jostling for position amongst the racecourse men. ${ }^{45}$ Hence, whilst ethnicity may have played a role in the formation of alliances, clearly other considerations need to be taken into account (access to gambling markets and protection of territory for example). ${ }^{46}$

Whilst Reuters model of 'disorganised crime' is a useful tool for problematising the fluid nature of these criminal networks, at least some of the events described in the 'racecourse wars' exhibited the hallmarks of organised criminal activity. ${ }^{47}$ Thus the management of the racecourse protection markets and the linkages between the racecourse gangs and the bookmaking fraternity and their associations, suggest some level of organisation. Nevertheless, protection rackets had long been familiar to the racing fraternity, and we know from Andy Davies's work that gang violence had been a feature of the later nineteenth century and the pre-war period. ${ }^{48}$ Why then does racecourse crime become such a problem by 1920 ? To a large part this is due to the shifting fortunes of the racecourses and gambling industry. Attendance at fixtures boomed after 1918 and, as Huggins has pointed out, there was a parallel rise in

\footnotetext{
${ }^{44}$ Thomas Burke, Nights in London (London, 1915), pp. 185-195; Lucio Sponza, Italian Immigrants in Nineteenth Century Britain: Reality and Images (Leicester, 1988).

${ }^{45}$ Brian Mcdonald, Elephant Boys: Tales of London and Los Angeles Underworlds (Edinburgh, 2000), p.81; Morton, East End, pp.119 - 140; Morton, Gangland: London's Underworld (London, 1992), pp.1 32.

${ }^{46}$ In Glasgow, Davies has pointed to the specific importance of sectarianism as well as structural issues associated with employment, 'Glasgow's 'Reign of Terror': Street Gangs, Racketeering and Intimidation in the 1920s and 1930s', Contemporary British History, 21/4 (2007), pp. 405-427, see pp. 408-9.

${ }^{47}$ Heather Shore, 'Undiscovered Country': Towards a History of the Criminal Underworld', Crimes and Misdemeanours: Deviance and the Law in Historical Perspective, 1:1, April (2007), p.10; Wright, Organised Crime, pp.2-3.

${ }^{48}$ Andrew Davies, 'Youth Gangs, Masculinity and Violence in Late Victorian Manchester and Salford', Social History, 32/2, (1998), pp.349-69; Geoffrey Pearson, Hooligan: A History of Respectable Fears (London, 1983).
} 
racecourse crime.$^{49}$ There had been attempts to control working-class gambling with the passage of the pre-war Street Betting Act of 1906. However, the act was largely unenforceable, and arguably fostered increased opportunities for police corruption (the police were closely associated with both on-course and street bookmaking. Ex-CID man Tom Divall was employed as a racecourse steward after his retirement in 1913, and in the 1930s, Frederick 'Nutty' Sharpe, formerly of the CID, faced accusations of corruption, when he moved into the bookmaking trade). ${ }^{50}$ Moreover, the anti-gambling lobby that had had such an impact in the late nineteenth century was greatly waning in influence. The mouthpiece of the anti-gambling establishment, the National Anti-Gambling League (NAGL) had a limited impact by the 1920s, when it became less coherent and influential. ${ }^{51}$ By the interwar period, the weakening influence of anti-gambling bodies, the lack of a national organisation to control the bookmaking industry arguably contributed to the vulnerability of the racecourses to racketeering and other gamblingrelated crime. Whilst a South of England Bookmakers Protection Association had been established in 1921, the fact that two of its early stewards were race-gang members is hardly indicative of its effectiveness. ${ }^{52}$ Charles Sabini and Alf White were among eight stewards appointed when the Association was set up in 1921, as was apparently Philip

\footnotetext{
${ }^{49}$ Huggins, Horseracing, p. 146.

${ }^{50}$ Street Betting Act 1906 [6 Edw. 7, c. 43]; David Dixon, From Prohibition to Regulation: Bookmaking, Anti-Gambling and the Law (Oxford, 1991), pp. 129-131, 146-7. Tom Divall, Scoundrels and Scallywags, and Some Honest Men (London, 1929); for Sharpe see TNA: MEPO 31/759, 'Enquiry about ex-Chief Inspector Sharpe'.

${ }^{51}$ Dixon, From Prohibition to Regulation, p.99; Andrew Davies, 'The Police and the People: Gambling in Salford 1900 - 1939', Historical Journal, 34 (1991), pp. 87 - 115; Ross McKibbin, 'Working-Class Gambling in Britain, 1880-1939', Past and Present, 82/1 (1979), pp. 147-178.

${ }^{52}$ See TNA: MEPO 3/1581, 'CID Report from Wm Brown, 1 December 1922'. The Bookmakers and Backers Racecourse Protection Association (BBRPA), What It Has Done and What It Can Do, with YOUR Help (National Association of Bookmakers (NAB) File, 'History', 1921), BBRPA, General Committee, Minutes, pp.1921. The BBRPA and NAB archives no longer survive.
} 
Emmanuel, son of Edward. ${ }^{53}$ However, by September 1922, as a result of allegations against the Sabinis, the 'stewards' services were dispensed with. ${ }^{54}$ The most lucrative protection rackets were concerned with bookmaking and betting, which were enjoying a surge of popularity in the post-war period. ${ }^{55}$ The rackets essentially rested on control over the right to operate as a bookmaker, and run a stand. Prior to the First World War, confrontations over the control of the pitches were common. After the war, the control of the pitches was increasingly taken over by organised protection; the race-gangs offered protection to bookies and controlled the allocation of pitches ${ }^{56}$ Moreover, as Carl Chinn has shown, the organisation of racecourse protection became increasingly territorial in this period. William Kimber oversaw the 'northern' courses, whilst the Sabinis controlled the 'southern' courses. ${ }^{57}$ According to Frankie Fraser who briefly worked for the Sabinis as a small boy, 'If the bookmaker wanted a pitch he had to pay the Sabinis. They sold him the tissues on which he put up the names of the runners, they sold him chalk to write the odds, and they had little bucket boys who brought a sponge round to wipe off the odds, ${ }^{58}$ It was not until 1928, and the passage of the Racecourse Betting Act that supervision of the pitches would become more effective. The extent to which the practices of extortion and protection had actually increased in the post-war period is perhaps debateable. However, the intensity of the 'turf-wars' that were being played out on the largely unsupervised racecourses does seem to have been a specific feature of the

\footnotetext{
${ }^{53}$ According to Morton, Philip Emmanuel went on to become the Association's vice-president. Morton, East End Gangland, p. 125. However, according to recent articles in The Racing Post (29 June, 3 July 2006), Edward Emmanuel was the vice-president of the Association.

${ }^{54}$ BBRPA General Committee, Minutes, 15 May, 12 June, 4 September 1922.

${ }_{55}^{55}$ Huggins, Horseracing, pp. 1 - 3, passim.

${ }^{56}$ Thomas Henry Dey, Leaves from a Bookmaker's Book (London, 1931).

${ }^{57}$ Carl Chinn, Better Betting With a Decent Feller: Bookmaking, Betting and the British Working Class, 1750 - 1990 (Hemel Hempstead, 1991), p. 178.

${ }^{58}$ Frankie Fraser, Mad Frank: Memoirs of a Life of Crime (London, 1994), p.13.
} 
1920s, although there were still problems at the Epsom and Brighton Downs by the 1930s since it was impossibly to fully enclose and regulate these areas. ${ }^{59}$

\section{Part Two}

\section{Anonymous Letters, Anti-alienism and the English 'Tommy'}

During the 1920 s constructions of the foreign criminal would frequently be drawn on by both press and police. The police would investigate the clubs and restaurants owned by Chinese, Russian Jews, Italians, and 'men of colour' like James Kitten, a native of Sierra Leone. ${ }^{60}$ Whilst, as David Cesarani has argued, anti-alienism was rooted in British political culture and society by the late Victorian and Edwardian period, it accelerated in the post-war period. According to Cesarani, wartime animosities, the repercussions of the Russian Revolution, economic dislocation and socio-political crisis, fuelled anti-alienism, forced it into the political limelight between 1918 and 1924, leading to a series of draconian controls from 1919 until 1929. ${ }^{61}$ Moreover, theories of degeneration were recast in the 1920s when Englishness was being redefined for a new generation. As Stefan Slater has demonstrated, foreigners were frequently subject to police attention throughout the period. ${ }^{62}$ However, despite the foreign-sounding names of many of the participants of the racecourse wars, the press only made sporadic references to their ethnicity. Certainly, there were some references to the 'foreignness' of the participants. For example, in April 1921, when clashes between racing-gangs were reported at Alexandra Park, in North London, there was commentary about Italians and 'Foreign

\footnotetext{
${ }^{59}$ Chinn, Better Betting, p. 182.

${ }^{60}$ TNA: HO 144/22301, 'Imposition and revocation of closing orders on restaurants and clubs used by aliens for gambling and prostitution', 1922-3.

${ }^{61}$ Cesarani, 'An Alien Concept?', p. 37.

${ }^{62}$ Stefan Slater, 'Pimps, Police and Filles De Joie: Foreign Prostitution in Inter-war London', The London Journal, 32/1 (2007), pp.53-74, p. 65.
} 
Jews'. The Times noted that the use of firearms 'had become fashionable with desperate men', and that 'much more could be done to keep these wretched foreigners in subjection than is generally done'. ${ }^{63}$ An editorial the following day also commented on the presence of 'undesirable rogues - some of them aliens' ${ }^{64}$ However, the Italian identity of the participants did not seem to be particularly noteworthy until the events of 1923, when fights broke out between the Sabinis and the Cortesis. The location of the confrontation in an Italian club, in the Italian quarter, saw it being constructed as essentially a 'faction fight' of the Italian community. At the Old Bailey trial of the Cortesi brothers in January 1923, Inspector Grosse of the C.I.D presented the 'remarkable story' of the feud between the brothers. Rather than being seen as one of the series of events that had taken place over the previous year the conflicts were portrayed as breaking out of ethnic communities. Mr. Justice Darling drew on Italian history to describe both the defendants and the victims as 'lawless bands'. ${ }^{65}$ Indeed, this tone had already been established by the Grand Jury who had strongly recommended, 'that in the event of any of the prisoners being found guilty who may be alien to this country that such should be deported as undesirables' ${ }^{66}$ Nevertheless, in contrast to the events surrounding the drug scandals that also punctuated the post-war years, the emphasis on alienism as a specific trope, was limited.

However, correspondents to the Home Office and police frequently resorted to the antagonistic pairing of foreigners and Englishmen (and Englishness more generally) to

\footnotetext{
${ }^{63}$ The Times, 4 April 1921, 'Racecourse Riot'.

${ }^{64}$ The Times, 5 April 1921, 'Racing and Ruffianism'. See also 26 July 1921, 'Roughs at the Races'.

65 'Sabini Case Sentences', The Evening Standard, 18 January, 1923.

${ }^{66}$ TNA: CRIM 1/209, 'Cortesi, Augustus Cortesi, George Cortesi, Paul Cortesi, Enrico Tomaso, Alexander Charge: Attempted murder'. Justice Darling issued a general warning to the Italian colony that those who got convicted in future would be turned out of the country with their wives and children, The Times, 19 January 1923. See also The Star, 5 December 1922; Evening Standard, 18 January 1923.
} 
shape their accusations. There are a number of references to anonymous accusations in Home Office and Metropolitan Police files, although only a small number of actual letters survive. ${ }^{67}$ Whilst police use of informers was well established, it is unclear how seriously anonymous complaints and tip-offs were generally taken. ${ }^{68}$ In 1924, when the Metropolitan Police were already subject to accusations of misconduct, the Report of the Commissioner of Police of the Metropolis, stated that complaints whether anonymous or not were all taken seriously, however, 'Most of the anonymous letters received are connected with street betting, gambling, etc., and for the most part emanate from persons who have some axe to grind'. ${ }^{69}$ 'Tommy Atkins', the pseudonymous author of the letters that were sent to the Home Secretary Edward Shortt in September and October of 1922 (a third letter was received which does not survive), may have had an axe to grind, but he also fundamentally understood the importance of adopting a language in which an 'Exservice man' and 'Englishman' informed the Home Secretary about the 'foriegners' (his spelling). The first letter, received on 21 September, complained about the racecourse gangs, and particularly what the writer asserted to be the tolerance of them by the Flying Squad:

'The Financier and Brains of this gang of Cuthroat[s] on the Race Courses of England are Foriengers [sic] named Edward Emanual and Gurchan Harris, these two men finance all the large clubs and Gambling Houses in the West End of

\footnotetext{
${ }^{67}$ See TNA: HO 144/10430, anonymous letters dated 21 September 1922, 5 October 1922, 11 June 1923; 8 December 1928; MEPO 3/1581, anonymous letters dated 20 September 1922, 23 August (1922?); The police also refer to other letters which have not survived (see memo in HO 144/10430).

${ }^{68}$ According to the Home Secretary Edward Shortt in a House of Commons debate in July 1922, the received, 'an enormous number of anonymous letters about all sorts of people'. See 'Police Protection of Life', Parliamentary Debates (Commons), 155, 23 July 1922, 1533-43.

${ }^{69}$ House of CommonsParliamentary Papers, Report of the Commissioner of Police of the Metropolis for 1924, p. 7.
} 
London, and they pay large sums of money to other foriengers [sic], "The Sabini Gang" also the "Flying Squad" of Scotland Yard to safeguard their interests'. ${ }^{70}$

The 'Tommy Atkins' letters were investigated by the Metropolitan Police with some vigour. Perhaps because the letters were directed to the Home Office, prompting a request for an investigation from the Home Secretary, or perhaps in response to the accusations of corruption, the police response was prompt. On 2 October 1922 an advertisement was placed in the personal column of the Daily Express as follows: 'Tommy Atkins, please supply full details, would it not be possible to arrange a private and personal interview, time and place at your disposal ${ }^{71}{ }^{71}$ A second letter arrived at the Home Office on 5 October. This letter provided a detailed numbered list of 'events' and names. At the conclusion of the letter 'Tommy Atkins' wrote, 'If you inquire into some of the above names, you may be able to reconstruct your evidence against this Wild, Foreign, Murderous Band of Italian Jews'. ${ }^{72}$ The material in the file, which spans 1922 to 1928, suggest the Home Office kept a watching brief on the gangs. However, a further anonymous letter that arrived on 11 June 1923 was not passed on to the police. This made accusations about the Sabinis and again referred to police collusion particularly in relation to Edward Emanuel, who was described as the owner of the Titchbourne Club in the Edgware Road, 'it is really remarkable the numbers of police officers and CID men who are continuously in this man's company well knowing that he is an ex convict felon and a rogue'. ${ }^{73}$ The police had also received anonymous letters making similar allegations. A letter that arrived after the Mornington Crescent Shooting of 19 August

\footnotetext{
${ }^{70}$ TNA: HO 144/10430, 'Letter from Tommy Atkins to Home Secretary, Edward Shortt', 21 September, 1922'.

${ }^{71}$ TNA: HO 144/10430, 'Letter from Chief Inspector Brown, 2 October, 1922'.

${ }^{72}$ TNA: HO 144/10430, 'Letter from “Tommy Atkins”, 5 October 1922'.
} 
was particularly damning about the favoured treatment shown to the 'Italian Mobs', in contrast to the 'Englishman' who 'only wants Fair Play, and justice done...' 74 Throughout the letter the dichotomous relationship between the 'Englishman' and the 'Italians', is constantly re-iterated; the police are drawn as having made a choice between good and evil, 'and what is more the Police are against him for why, because he happen to be Englishman, if he, had been an Italian, there would have been know notice taken off the charge...'. A second letter was received 26 September 1922, was the most specific in relation to police corruption. This letter, which claimed to be from a group called the 'Timewell Force', accused a Flying Squad Detective named Rutherford of having been drinking with the Sabinis on the night of the Gray's Inn Road incident, 'I first of all refer to the shooting case in the Italian Colony, when Rutherford was supposed to have been shot at. He was drinking with these men in a certain Public House, and words which were passed by this famous detective and these loafers in the betting world, the shots were among themselves and not in any direction for this drunken detective and one of the Flying Squad' ${ }^{75}$ The police response to the allegations of corruption, and specifically to the 'Tommy Atkins' letters, was to produce a twelve page report countering the accusations on a point-by-point basis; describing the police actions in each of the incidents of which they knew something, and the outcomes of any trials, including details of failed prosecutions. Moreover, whilst the report acknowledged the participation of 'habitues of the Clerkenwell district' and 'members of the Jewish persuasion', it referred

\footnotetext{
73 TNA: HO 144/10430, 'Anonymous letter', 11 June 1923'

${ }^{74}$ TNA: MEPO 3/1581, 'Anonymous letter', 23 August 1922'.

75 TNA: MEPO 3/1581 ,'Letter from the Timewell Force, dated 20 Sept. 1922', 26 September 1922'. Timewell presumably refers to James Timewell, the leader of the Police and Public Vigilance Society, which in the early 1900s had been devoted to uncovering police corruption, James Timewell, Royal Commission on the Metropolitan Police (London, 1907). Stefan Petrow, Policing Morals: The Metropolitan Police and the Home Office, 1870 - 1914 (Oxford, 1994), pp. 24-25.
} 
more generally to 'the rougher elements of the race course frequenters' and 'London thieves of the worst type'. ${ }^{76}$ The letter writers then drew on distinctions between 'Englishmen' and 'foreigners' that clearly had meaning in the interwar period. Matt Houlbrook has noted that the Great War provided the context, 'in which pervasive and recurring historical anxieties around the instability of categories of gender or class acquired greater resonance in the 1920s' ${ }^{77}$ The letters suggest that categories of 'Englishness' and 'foreignness' were equally problematic. The police themselves were not convinced by the appeal to 'Englishness', suggesting in at least one case that the letters were written by rival 'partisans'. Superintendent Frederick Wensley explicitly linked the writing of anonymous letters to 'foreigners or persons of foreign extraction, who, for a fee, wrote anonymous letters under a nom de plume such as "Lover of Justice", "British Rate-payer", “An Englishman", "A Starving Wife”, etc., etc.'.78 Moreover, it is clear that the categorisation of Englishness in this period was fundamentally problematic. Whilst J. A. Black has emphasised the importance of Englishness in moulding perceptions of the English soldier during and after the Great War, police investigations into the racecourse gangs show us that 'foreignness' and 'Englishness' were not mutually exclusive. ${ }^{79}$ Moreover, whilst the police were not unresponsive to the language of Englishness, with occasional references to the 'Italian colony' and to 'English-born' racing-men, this was not their main concern. ${ }^{80}$ This was most strongly reserved for the allegations of corruption and incompetence to which they

\footnotetext{
76 TNA: MEPO 3/1581, 'Letter from Wm Brown to Superintendent 2 October 1922'; 'CID Report from Wm Brown 1 December 1922'.

${ }^{77}$ Houlbrook, 'Powder Puff', p. 161.

${ }^{78}$ TNA: MEPO 3/374, 'Note attached to report from Wm Brown, 27 October 1924'.

${ }^{79}$ J. A. Black, "Who dies if England live?": Masculinity, the Problematics of Englishness and the Image of the Ordinary Soldier in British War Art, c. 1915-28', in Stephen Caunce, Ewa Mazierska, Susan SydneySmith and John K. Walton (eds), Relocating Britishness (Manchester, 2004), pp. 148-166, at p. 149.
} 
were subject. Police concerns about the 'enemy within', resonates with growing contemporary anxieties about the relationship between 'neurasthenic', 'malingering' and 'degenerate' ex-service men and a propensity to criminality. ${ }^{81}$

\section{Racing Men and War Veterans}

'Tommy Atkins' may have defined himself as an Englishman and the racecourse gangs as 'other' but police investigations into the military service records showed that many of the racing men were also former 'Tommies'. War was fundamentally seen as a catalyst in the arming of the post-war criminal and its negative effects were frequently remarked upon. As one editorial on 'Racing and Ruffianism' in the Times of 1921 commented, 'They are, like other manifestations of the present disregard for the rights of property and the sacredness of human life, one of the vile products of the war' ${ }^{82}$ This brew of guns and war clearly informed the rhetoric of 1920 to 1922 . Charles Leach, the ex-Divisional Detective Inspector, writing in 1933, believed 'that the war had produced a potential, and particularly dangerous criminal among 'the War veterans", ${ }^{83}$ Looking back in 1931, Chief Constable of the CID, Frederick Wensley commented not only on the impact of war, but suggested that some criminals may have simply returned to their pre-war activities: 'Among the large number of boys and men who had become temporary officers were those who were unwilling to revert back to their normal stations in civil life, and took to the quest of "easy money". Many old criminals returned. Of the flood of men who were released from the services there was a proportion who, for one reason or

\footnotetext{
${ }^{80}$ For example see TNA: MEPO 3/1581, "CID Report into "Race Gang Feuds"'.

${ }^{81}$ Bourke, Dismembering, p. 119.

${ }^{82}$ The Times, 5 April, 1921.
} 
another, fell into crime'. ${ }^{84}$ This would be borne out in the investigations into the first substantial affray in the racecourse wars. ${ }^{85}$ In gathering evidence against the accused not only were previous convictions sought, but also their military records. For example Joseph Witton and William Stringer were formerly of the Worcestershire Regiment. Witton had seen service in France and Gallipoli, but had also deserted twice and was eventually discharged from the Army after being convicted as a civilian for shop breaking in Birmingham, in September 1918. Stringer had seen action in France, but had deserted in 1916, 1917, and 1919, and again had been discharged due to a civil conviction for being 'an Incorrigible Rogue' whilst in a state of desertion, in April 1920. A number of racing men had pre-war records. Despite his apparent innocence, the pre-war record of one of the victims of the 'Battle of Epsom' Charles 'Woolf' Schwartz was requested by the police, probably because he was a known criminal who had pursued a vigorous career in crime both before and after deserting from the $28^{\text {th }}$ Middlesex Regiment in 1915 or 16. ${ }^{86}$ According to the report from the District Divisional Detective at Brixton, the investigations into war records informed the sentencing, as much as previous convictions. ${ }^{87}$ Patterns of desertion, civilian crimes, and pre-war records were repeatedly exposed in investigations into the character of the racecourse men throughout the early 1920s, suggesting a high degree of recidivism and 'career' criminality, rather than men criminalised by the trauma of war. For example, Joseph Jackson, one of the Birmingham gang involved in the shooting of Detective Rutherford in Gray's Inn Road in August

\footnotetext{
${ }^{83}$ Charles E. Leach, On Top of the Underworld: The Personal Reminiscences of Ex Divisional Detective Inspector Leach (London, 1933), p.3.

${ }^{84}$ Frederick Porter Wensley, Detective Days: The Record of Forty-two Years' Service in the Criminal Investigation Department (London, 1931), p.214.

${ }^{85}$ TNA: MEPO 3/346, 'Report from Inspector Berrett'.

${ }^{86}$ TNA: MEPO 3/346, Infantry Record Office, Warwick; 'Particulars taken from file of Woolf Schwartz, C.R.O No. S146229'.
} 
1922 had enlisted in the army in 1906, and subsequently had a varied career of desertion and petty crime. In November 1908, he had been convicted for striking an officer and damaging a band instrument, for which he received 84 days detention. He deserted in December 1910, but re-enlisted in 1914. Throughout 1914 to late 1916, he seems to have spent much of his time deserting, re-enlisting, and spending time in prison. In January 1917, he was convicted of felony and received eight months imprisonment. However he does not seem to have served out this sentence. In April 1917, he received fourteen days field punishment for absence from the $5^{\text {th }}$ Battalion Rifle Brigade; in June he was transferred to the Labour Corps, and on 30 November 1917 he was discharged as no longer physically fit. The police report noted that, 'He has suffered from shell shock and neurasthenia and his character is marked 'Bad", ${ }^{88}$ A further report from Detective Sergeant Walter Selby of New Scotland Yard, noted that Jackson, a father of five children under the age of eleven, received an army pension and had undertaken some casual work. Selby noted, 'Even whilst he was in the Army and under treatment in a Military Hospital he demanded money from shopkeepers and costermongers in Bermondsey'. Jackson's pre-war record was given in evidence at his trial in November 1922, although his defence noted that for two years he had been the secretary to the local branch of the Discharged Soldiers Society. This did not cut any ice, as Jackson was sentenced to seven years penal servitude. ${ }^{89}$ Walter Selby also reported on William Edwards from Hoxton (a Sabini man), who he described as 'a persistent criminal with 18 previous convictions to his discredit for larceny, assault on Police, under Prevention of

\footnotetext{
${ }^{87}$ TNA: MEPO 3/346, 'Report from Divisional Inspector, Brixton Station, 28 July 1921'.

${ }^{88}$ TNA: MEPO 3/1579, 'Nottingham City Police, General Report, 31 August, 1922, Re: Joseph Jackson, C.R.O: $8523 / 1916$ '.

${ }^{89}$ News of the World, 5 November 1922.
} 
Crimes Act and as a Incorrigible Rogue'. Edwards had joined the $5^{\text {th }}$ Royal Fusiliers in February 1915, and in April 1918, he was sentenced to 12 months for attempting to pickpockets, 'He was released on $15^{\text {th }}$ February, 1919, and handed over to a Military Escort from which he escaped the same day and from then was shown on his Army Records as a deserter, ${ }^{90}$

Whilst there is no quantifiable relationship between the military record and the pattern of sentencing, the war clearly cast a long shadow. Both in the collection of evidence, and within the space of the courtroom, the experience of soldiering and the 'character' gained; good, bad, or indifferent, were clearly regarded as crucial in shaping criminal identity. Moreover, criminals themselves recognised the importance of wartime service. For example, one of the Birmingham men, Thomas Hurley, wrote to the police directly about his character. As well as providing employment references, the letter carefully detailed his wartime and post-war experience in the Royal Army Service Corps, where he was batman to a Captain Williams, MC, in Cork, Ireland. ${ }^{91}$ Indeed, not all the 'racing men' who had fought in war had poor army records. For example, Joseph Sabini joined the Royal Welch Fusiliers in March 1916 and went overseas with the British Expeditionary Force, his character was assessed as 'good'. ${ }^{92}$ In November 1924, when Sabini man Alfred Solomon was charged with the murder of Barnett Blitz in a club shooting, both his Q.C, Sir Edward Marshall Hall and Divisional Detective-Inspector Hanbrook, who appeared as a defence witness sought to establish Solomon's credibility with reference to his war record. Marshall Hall, 'put in the prisoners military record,

\footnotetext{
${ }^{90}$ TNA: MEPO 3/1579, 'Rex V. Jackson and Others. Antecedents of Jackson, Edwards, Phillips, and Fagioli'.

${ }^{91}$ TNA: MEPO 3/346, 'letter from Thomas Hurley, from Brixton prison, 28 June 1921'; also 'R.A.S.C Record Office, Confidential reports'.
} 
which stated that he served in the Army for over four years during the war and had a very good character and was entitled to a number of medals ${ }^{93}$ The case was presented as essentially self-defence, with the attack on Blitz coming after a struggle in which Blitz had apparently violently attacked Solomon's associate Edward Emmanuel. Solomon was eventually found guilty of manslaughter and sentenced to three years penal servitude. Despite an extensive criminal record and involvement in violent crime, Marshall Hall choose to counter this with Solomon's war record. Moreover, the question of the participant's Jewish identity was handled in a contradictory manner. Both Solomon and Blitz were clearly associated with the Jewish community, and the location of the killing was in the Eden Club, described by Marshall Hall as 'frequented mostly by the racing fraternity, members of the Jewish persuasion, and the sooner that sort of place was shut by the better for everybody concerned'. Nevertheless, Solomon's Jewish identity seemed to be of little significance. Indeed since the Jewish community was also providing funds for the defence, this showed, according to Marshall Hall, 'that prisoner could not be such a scoundrel as had been suggested' ${ }^{94}$

Ethnicity is clearly an important factor in understanding the territorial alignments upon which the gangs were organised. However, whilst the ethnic identity, whether Jewish or Italian, of the participants was a factor in the racecourse wars, their identity as 'Tommies' and members of the metropolitan criminal fraternity, seems to have been equally if not more significant. By the mid-1920s commentators were still of a mind to blame the war for anti-social behaviour. As one writer to The Times, Francis H. Skrine commented 'The Great War is responsible for many recruits to the army which preys on

\footnotetext{
92 TNA: MEPO 3/1581, 'Infantry Record Office, No. 52060, Pte Joseph Sabini, 8 September 1922 '.

${ }^{93}$ This may have simply referred to the service medals that all serving soldiers were entitled to.
} 
society. Few men can have spent six years in licensed disobedience to the sixth commandment without retaining anti-social traits'. ${ }^{95}$ Senior police officers apparently shared this view. In 1925, in a letter to the Secretary of State, Assistant Commissioner William Horwood noted that, 'Experienced police officers are of the opinion that there are several contributory factors assisting to keep alive the spirit of unrest and indiscipline which, if not resulting from the War, were generally strengthened by it'.96 Unsurprisingly, given the age-demographics of the gangs, ex-soldiers did number high amongst the post-war criminal fraternity. Nevertheless, as Horwood implies and the evidence suggests, rather than being directly a product of the war, soldiering and crime were not mutually exclusive. It may be that in the case of many of these men, demobilisation meant picking up from where they had left off before the war. Indeed, soldiering was frequently felt to be a means of reclaiming offenders. The idea that the war had criminalised and brutalised soldiers, producing a 'new' post-war criminal does not seem to be substantially supported by the evidence which suggests that the men involved in the racecourse gangs, were tied into criminal, neighbourhood and ethnic networks which had withstood the impact of war.

\section{Press, Police and the 'Racecourse Terrorists'}

The cultural influence of the war was evident in the press coverage of the racecourse gangs, which focussed overwhelmingly on the open public violence, the eruption of ruffianism, and the dramatic production of firearms and other weaponry rather than the foreignness of the participants. The arming of criminals in the period was seen as a growing problem, and at the peak of the race-gang violence there was a tendency towards

\footnotetext{
${ }^{94}$ The Morning Chronicle, 19 November 1924.

95 The Times, 'Epidemic of Crime', 20 December 1924.
} 
luridness in much of the press coverage, with headlines such as 'Razors and Revolvers', 'Shooting Sensation' and 'Wild West Scenes in Streets of London' ${ }^{97}$ In August 1922, the Times printed an editorial on 'Armed Criminals', claiming, 'Among the many evil consequences of the war none is a greater danger to the community than the growing abuse of firearms' ${ }^{98}$ Whilst the Boer war and the Irish conflict had helped the circulation of weapons, the press made a distinct connection between the war and the arming of criminals, 'Before the war it was extremely rare for a burglar to carry a firearm, the ordinary thief never did so, and the so-called 'hold-ups' or daylight raids on shops were rarely accompanied by the production of revolvers'. In fact, armed crime had declined during the war, partly as a response to the restrictions that had been introduced by the Defence of the Realm Act. ${ }^{99}$ Nevertheless, the Firearms Act had been passed in 1920 to combat what was felt to be a growing problem. ${ }^{100}$ The then Home Secretary Edward Shortt had stated that the purpose of the bill was '... designed to maintain greater control so that, as far as possible, criminals or weak minded persons and those who should not have firearms may be prevented from having these dangerous and lethal firearms'. ${ }^{101}$ The Blackwell Committee Report of 1918, which had led to the Act, had commented on the possibility of the criminal classes who had served in the army, procuring or retaining service revolvers. ${ }^{102}$ Arguably, the Firearms Act was felt necessary to prevent a flood of demobilised soldiers brandishing their service weaponry. In the headlines that would

\footnotetext{
${ }^{96}$ TNA: HO 45/12278: 'Letter from Sir William Horwood, 19 October 1925'.

${ }^{97}$ News of the World, 13 August 1922; 6 August 1922; 27 August 1922.

${ }^{98}$ The Times, 26 August 1922.

${ }^{99}$ The Annual Criminal Statistics for England and Wales. Cited in Emsley, 'Violent Crime', p.27.

${ }^{100}$ The Firearms Act of 1920 [10 \& 11 Geo. 5. CH. 43.]

101 'Firearms Bill [Lords]. Mr Edward Shortt', Parliamentary Debates (Commons), 130, 8 June 1920, 3619.

${ }^{102}$ TNA: RECO 1/342, 'Report by the Committee on the Control of Firearms to the Minister of Reconstruction'.
} 
accompany the race-gang affrays in the early 1920s, it was this image of an armed and lethal 'criminal class' that was drawn upon most powerfully. Thus the imagery of 'war' and 'battle' was frequently resorted to in the descriptions of the conflicts, particularly at the peak in August 1922, and again in the resurgence of race-gang activities in 1925. Metaphors and symbols of conflict had perhaps been most prominently employed in the 'Battle of Epsom', or Ewell of June 1921. Thus the Jewish bookmakers who had attacked, had been travelling in that most ubiquitous of military vehicles, the Crossley Tender. ${ }^{103}$ Moreover, the dramatic intervention of Police Sergeant Dawson who singlehandedly held up the men at the George and Dragon Pub, warning, 'The first man who moves I will shoot', vividly conveyed the heat of battle. ${ }^{104}$ In various accounts throughout the summer and autumn of 1922 the race-gangs were described as 'Armed Desperadoes', 'Dangerous Ruffians', 'Racecourse Terrorists' and 'The Terror of the People'; affrays in which they were involved referred to as the 'Camden Town Battle', and 'Gray's Inn Battle'; witnesses and bystanders referred to as 'Courageous Civilians'. ${ }^{105}$ On 24 August an Evening Standard report read, 'War Declared on Race Gangs'; the Standard had clearly cast the race-gangs as terrorists, claiming the following day that "while Scotland Yard is thus rigorously engaged in hunting down the terrorists, the 'enemy' is employing a sort of secret service to ascertain the movements of detectives'. ${ }^{106}$ In 1925, this rhetoric was dramatically stepped up, when a series of incidents allegedly involving 'racing men', attracted the attention of the crusading Home

\footnotetext{
103 TNA: MEPO 3/346, 'Samuel Barnett's statement, 4 June 1921'; 'Report from Wontner \& Sons, Solicitors, 26 July 1921'.

${ }^{104}$ Surrey Advertiser \& County Times, 23 July 1921.

${ }^{105}$ Evening Standard, 24, 25, 30 August 1922; The Star, 5 December 1922 News of the World, 17 September, 1 October, 5 November 1922.

${ }^{106}$ Evening Standard, 24, 25 August 1922.
} 
Secretary, William Joynson-Hicks. In August 1925 the Daily Express printed a list of 'gang outrages', which had apparently occurred in London and other parts of the country between March 1924 and August 1925. For instance, in February 1925, five men were wounded in Aldgate by razor-slashing and kicking in full view of a large crowd; in April, five men set upon another man with razors and iron bars behind Euston Station; in August, twenty members of two gangs fought with razors in Shaftesbury Avenue. ${ }^{107}$ The country, it seems, was gripped by rowdyism and the Home Secretary had made a declaration of war on the race gangs. Nevertheless, Joynson-Hicks seems to have joined on the bandwagon at a fairly late stage, reacting largely to the most recent and sensationalist tabloid coverage. ${ }^{108}$ The Daily Mail reported, 'It is the view of the Home Secretary that this state of affairs should not be permitted to continue, since it creates a menace to the community, ${ }^{109}$ The Metropolitan Police were pressed to explain the gangs' activities and to suggest the best ways of coping with the racecourse gang problem. ${ }^{110}$ Despite the Home Secretary's pronouncements, and press references to 'racegang' terrorism, other politicians and the police were much more sceptical. Indeed, the police seem to have been keen to underplay the disturbances, and emphasise the influence of the press. Writing in 1925, in response to letters from the Home Secretary William Joynson-Hicks, Police Commissioner Sir William Horwood pointed to the structural problems in policing race meetings, and the "overworked press term of "race-gangs", pointing to the tendency of the press to label petty disturbances as race-gang related. ${ }^{111}$

\footnotetext{
${ }^{107}$ Daily Express, 24 August 1925.

${ }^{108}$ See Huw F. Clayton, “A Frisky, Tiresome Colt?" Sir William Joynson-Hicks, the Home Office and the “Roaring Twenties" 1924-1929', PhD, University of Wales, Aberystwyth, 2009, vol. 2.

109 The Daily Mail, 24 August 1925.

${ }^{110}$ TNA: HO 45/12278, 'Letter from William Horwood to Secretary of State, 14 October 1925'.

${ }^{111}$ Ibid.
} 
As a response to the Daily Express reports, Horwood initiated a full investigation into the 'alleged disturbances by race gangs' in London. They found the version of events portrayed by the Express to be vastly overstated, with little evidence in many of the cases of any involvement of racing men. The razor fight in Shaftesbury Avenue was said to be 'pure invention', and, as a result of these investigations the Home Secretary instructed the police to 'go on "as you've been going"'. 112

\section{Conclusion}

After 1925 public attention was increasingly diverted from the racecourse gangs. Whilst the gangs were certainly still active and to some extent still subject to police investigation, they no longer had the public visibility that they had acquired during the peaks of 1922 and 1925. In June 1926, the reporting of the shooting of Albert Sabini by Francis Maiolini was rather more muted than similar reports at the height of the racecourse wars. ${ }^{113}$ It may also have been overshadowed by news that Charles Sabini had been threatened with bankruptcy. ${ }^{114}$ Sabini's financial problems may well have stymied the family's activities by the later 1920s. ${ }^{115}$ Possibly the gangs themselves scaled back their confrontations as a response to the media interest. According to most biographies of Charles or 'Darby' Sabini, he had by this time moved to the more salubrious environs of Hove (a seaside coastal resort, adjacent to Brighton); although Harry was still active in the London scene by $1935 .{ }^{116}$ Certainly whilst incidents associated with the Sabini family and/or the racecourse gangs would occur sporadically into the early 1930s, with the

\footnotetext{
112 TNA: HO 144/10430, 'CID Report, 1 December 1922'; 'Minutes, H.O., August 1925'.

113 The Times, 29 June 1926, 'Shooting Charge Sentence'.

${ }^{114}$ The Times, 30 June 1926, 'C. D. Sabini’s Affairs'.

115 Ibid. Also The Times, 16 December 1925, 'High Court of Justice, King's Bench Division, Race Gang Libel Action', 11 June, 'C. D. Sabini's Bankruptcy'.

116 The Times, 2, 14 May 1935.
} 
emergence of the White family as the dominant force in the racing and bookmaking fraternity by this time, there seems to have been a move away from the most violent excesses of the previous decade. ${ }^{117}$ Problems with protection rackets at the courses did not completely disappear in the 1930s. Most notably, clashes at Lewes racecourse apparently linked to the Sabinis would famously influence Graham Greene's depiction of the race-gangs in Brighton Rock, published in $1938 .{ }^{118}$ However, as Chinn argues, better local and national organisation of the bookmakers' interests clearly had an impact from the late 1920s and early 1930s. Thus Pitch Committees were formed to protect bookmakers' rights, and local associations were brought together in the National Association of Bookmakers from 1932. ${ }^{119}$ By the later 1930s the racecourse gangs had become a colourful feature of the roaring twenties. Indeed, looking back at his CID career from the late 50s, in his aptly named autobiography, War on the Underworld, Ted Greeno described much of the violence of 1925 as 'wildly exaggerated'; as he noted, perhaps unwittingly drawing the connection between the violence and press coverage, 'They were puffed up by their own headlines'. ${ }^{120}$

This article has explored the way in which a number of different cultural, social and political agencies responded to some forms of criminality in post-war Britain. Whilst it may be true to argue, as Clive Emsley has done, that the press and British society did not resort to demonising the brutalised Tommy, clearly the war did shape the construction of and response to the racecourse criminals, and arguably cast them as the 'folk-devils' of

\footnotetext{
${ }^{117}$ Morton, East End Gangland, pp. 135 - 140. For later Metropolitan Police files dealing with the White family see TNA: MEPO 3/910; for later race gangs references see TNA: MEPO 3/374.

${ }^{118}$ Huggins, Horseracing, p. 150. See Steve Chibnall, Brighton Rock (London, 2005).

${ }^{119}$ Chinn, Better Betting, pp. 181-184.

${ }^{120}$ Edward Greeno, War on the Underworld (London, 1960), p. 26.
} 
the aftermath. ${ }^{121}$ Indeed, as police investigations into criminal and war records demonstrate, the categories of soldier-hero - the stalwart Tommy Atkins - and racecourse gangster were not mutually exclusive. As Adrian Bingham has described, by the early twenties, the realities of war had begun to set in, and 'soldiers were in danger of becoming 'desensitized brutes'. ${ }^{122}$ The events described in this article offered a significant challenge to the police during a period when they were increasingly subject to criticism. Thus, Matt Houlbrook has referred to the 'explosive politics of law enforcement after the Great War'. ${ }^{123}$ Yet, in this critical period, the Metropolitan Police did not automatically draw on tropes of 'otherness' and 'foreignness', but rather sought to define the racecourse gangs as a product of the war, an 'enemy within'. Moreover, the associations with alienism, however insubstantial they were in the cases of some men, fundamentally allowed the press and the Home Secretary to characterise the metropolitan confrontations as something essentially unEnglish and potentially dangerous. The importance of Englishness was clearly something that was recognised by the actors in these events. Not only did law enforcers recognise the participants of racecourse affrays as former 'Tommies', not only did anonymous complainants seek to address their grievances as Englishmen, but racing men themselves drew attention to their national identity, their military service, their Englishness. With the rising tide of xenophobia in the 1930s, and the internment of Charles and Harry Sabini as Enemy Aliens in June 1940, this language retained its power. ${ }^{124}$ Interviewed for the appeal against his internment in

\footnotetext{
${ }^{121}$ Emsley, 'Violent Crime'.

122 Bingham, Gender, p. 196.

${ }^{123}$ Houlbrook, 'Powder puff', p. 148.

${ }^{124}$ The Home Office Advisory Committee (Italian), described Harry Sabini as 'a violent and dangerous criminal of the gangster type, liable to lead internal insurrections against this country', TNA: HO45/25720. See Lucia Sponza, 'The British Government and the Internment of Italians', in Cesarani \& Kushner (eds), Internment of Aliens, pp. 125 - 145.
} 
1940/41, Charles Sabini bullishly repudiated his Italian identity and asserted his Englishness, 'England is the only country for me'. ${ }^{125}$ A letter from Joseph Sabini, who wrote on behalf of his brothers in February 1941, pointed out that he had volunteered to fight in the Great War, and asked for his brothers release, 'as one true Britisher to another'. ${ }^{126}$

Wordage: 10,856 (including abstract and references)

${ }^{125}$ TNA: HO 45/23691, 'Octavius Sabini: Internment'.

${ }^{126}$ TNA: HO45/25720, 'Letter from Joseph Sabini, dated 2 February 1941’. 